\title{
A study on the relationship between perceived CSR motives, authenticity and company attitudes: a comparative analysis of cause promotion and cause-related marketing
}

\author{
Min Ah Jeon and Daechun $\mathrm{An}^{*}$ (D)
}

\author{
*Correspondence: dan@inha.ac.kr \\ Department of Business \\ Administration, Inha University, 100 \\ Inha-ro, Michuhol-gu, Incheon \\ 22212, South Korea
}

\begin{abstract}
In order to delve into the complexity involved in the role of authenticity in the context of CSR marketing, this study examines the relationships among perceived CSR motives, authenticity and company attitudes. A different effect of perceived CSR motives on authenticity is also examined between the two most representative types of CSR activities, namely, cause promotion and cause-related marketing. The results from a face-to-face survey with a sample of 289 respondents show that value-driven and stakeholder-driven motives had a positive effect on CSR authenticity while egoistic motives negatively affected CSR authenticity. Also, the effects of value-driven and stakeholder-driven motives on CSR authenticity were found to be larger for cause promotion than they were for cause-related marketing. However, the difference in the effects of the other two motives on CSR authenticity was not statistically significant between cause promotion and cause-related marketing. In addition, the effect of CSR authenticity on company attitudes was found to be statistically significant. When the relative strengths of the effects of four categories of motives on CSR authenticity were compared, value-driven motives had the strongest effect on CSR authenticity for both cause promotion and cause-related marketing. Interestingly, for cause promotion, stakeholder-driven motives had the second strongest effect while egoistic motives were least influential. For cause-related marketing, egoistic motives were found to be the second most influential factor, followed by strategic and stakeholder-driven motives. Practical implications of these finding are discussed along with theoretical implications.
\end{abstract}

Keywords: CSR motives, Authenticity, Cause promotion, Cause-related marketing, Company attitudes

\section{Introduction}

Literature suggests that consumers' perceptions of the motives behind a firm's CSR activities influence their attitudes toward the firm and buying intentions of the products of a sponsoring firm (Becker-Olsen et al., 2006; Brown and Dacin, 1997). When consumers perceive CSR motives truly be altruistic for society, namely authentic, firms' CSR actions positively influence consumer attitudes toward the company and its

(c) The Author(s). 2019 Open Access This article is distributed under the terms of the Creative Commons Attribution 4.0 International License (http://creativecommons.org/licenses/by/4.0/), which permits unrestricted use, distribution, and reproduction in any medium provided you give appropriate credit to the original author(s) and the source, provide a link to the Creative Commons license, and indicate if changes were made. 
products (Ellen et al., 2006). However, extant research ignores a possible difference in consumer perceptions of CSR motives between the two representative types of CSR activities, cause promotion (CP, hereafter) and cause-related marketing (CRM, hereafter), and the subsequent effects. Most studies treat CSR marketing activities to be identical in their motives, goals, and specific tactics so that they may generate universally similar effects in the mind of consumers.

Considering the differences in the goals, motives, and executional strategies between $\mathrm{CP}$ and $\mathrm{CRM}$, a meaningful difference is expected in the degree to which consumers perceive CSR motives to be authentic between them. Thus, this study tries to fill this gap in literature by comparing consumer perceptions of CSR motives between CP and CRM and examining the difference in the effects of CSR motives on CSR authenticity for CP and CRM. Specifically, the following research questions are addressed in the study: (1) Are there relationships between CSR motives and perceived CSR authenticity? (2) Is there any difference in the perceptions of CSR motives between CP and CRM? (3) What is the difference in the effects of perceived CSR motives on CSR authenticity between CP and CRM?

By addressing a possible difference in consumers' perceptions of CSR motives and their resulting effects on authenticity, this study may add new knowledge in understating consumers' reactions to different types of CSR activities and may help better understand the role of authenticity in explaining consumer reactions to CSR activities. Practically, this study may help CSR marketers in developing differentiated CSR strategies based on the level of consumers' perceptions of authenticity between CP and CRM.

\section{Literature review}

\section{CSR motives}

Previous studies suggest that the effectiveness of CSR activities depends on the degree to which consumers associate them with either egoistic or altruistic motives (Menon and Kahn, 2003; Mohr and Webb, 2005; Becker-Olsen et al., 2006). Researchers employed different approaches to categorize CSR motives. For example, Forehand and Grier (2003) categorized CSR motives as 'public-serving' and 'firm-serving, while Graafland and Van de Ven's (2006) scheme included 'strategic motives' and 'moral motives.' Similarly, Becker-Olsen et al.'s (2006) categories have 'profit motivated' and 'socially motivated.' However, claiming that consumers' attributions are more complex than traditionally viewed, Ellen et al. (2006) segmented CSR motives into four categories, self-centered motives that are strategic or egoistic and other-centered motives that are values-driven or stakeholder-driven.

Attribution theory addresses the processes by which individuals evaluate the motives of others' actions and explains how these perceived motives influence subsequent attitudes and behavior (Heider, 1958). In this vein, consumers attribute a firm's CSR motives based on various source of information (Forehand and Grier, 2003) and, thus, consumers' perceptions are different depending on their attributions of firm's motives for engaging in CSR activities (Becker-Olsen et al., 2006; Ellen et al., 2006). Despite the importance of CSR motives in explaining CSR effectiveness, there are not enough research on CSR motives. 


\section{CSR authenticity}

CSR authenticity refers to the degree to which consumers believe firm's CSR activities are truly for society as a whole, not for its own benefits (An, 2016). Alhouti et al. (2016) suggest that consumer evaluations of CSR activities usually come from their perceptions of whether or not firm's CSR motives are authentic because consumers tend to be suspicious about a hidden motive (i.e., making profits) of a firm performing CSR activities.

Beckman et al. (2009) argue that firm's CSR activities are properly assessed when various stakeholders' perceptions of authenticity are considered. While CSR authenticity helps win the support of hostile stakeholders, but the lack of authenticity leads to distrust and negative images of a firm (Beckman et al., 2009). It was also shown that CSR authenticity positively affects employees' perceptions of a firm regarding employee morale, dedication, loyalty, pride, and organizational homogenization (Bhattacharya et al., 2006). In this regard, Alhouti et al. (2016) conclude that it is not just enough for a firm to behave in a socially responsible manner, but its CSR activities need to be credible if a firm expects to reap rewards.

\section{Classification of CSR activities}

In an effort to draw a general framework of understanding consumer reactions to a variety of CSR actions, researchers have tried to develop a typology according to their goals, strategies, and executional tactics. For example, Kotler and Lee (2013)put them into six different types, including corporate cause promotion, cause-related marketing, corporate social marketing, corporate philanthropy, community volunteering, and socially responsible business practices. From a marketing perspective, An (2016) categorized them into four types, including cause promotion, social marketing, cause-related marketing, and CSV marketing. Since the purpose of this study is to examine how consumers perceive CSR motives of different actions and they influence company attitudes from a marketing perspective, the two most representative types of marketing-oriented CSR activities are chosen for this study: cause promotion and cause-related marketing.

Cause promotion $(\mathrm{CP})$ is one of CSR activities which intends to increase a level of awareness of a cause and to stimulate consumers' voluntary participation in supporting it. Since CP mainly focuses on communicating with the public and spreading out the intended message, an integrated marketing communication approach is used to contact with target audience. For example, an advertising campaign is developed to deliver messages to appropriate target audience, supported by PR activities and other promotional tools. On the other hand, cause-related marketing (CRM) intends to draw attention and consumer support for a cause through revenue-producing transactions (Varadarajan and Menon, 1988). For example, in a famous CRM campaign, called 'One for One' campaign of TOMS, TOMS donates a pair of shoes to help children without shoes in less developed nations every time a pair of its shoes is sold. Although CRM is also supported by communication tools in increasing awareness and induce consumer participation, its main goal is to sell the products and supporting the cause in a simultaneous manner. 
Although both CP and CRM have an identical goal of supporting a cause, their executional tactics are different. As far as consumer perceptions of CSR motives are concerned, CP seems to be more altruistic than CRM while CRM appears to be oriented more toward generating revenues through stimulating consumers' purchase behavior.

\section{Hypotheses and research questions}

This study intends to examine the relationship between perceived CSR motives, authenticity and company attitudes and the difference in the effects of perceived CSR motives on authenticity between CP and CRM. In doing so, Ellen et al.'s (2016) four-category scheme of CSR motives are used: (1) value-driven motives, (2) stakeholder-driven motives, (3) strategic motives, and (4) egoistic motives. The research model is presented in Fig. 1.

CSR actions are considered value-driven when companies engage in CSR activities purely because of their moral, ethical, and social standards (Ellen et al., 2000). Consumers may believe that the company cares about the cause and has a genuine concern about social problems. In this case, CSR activities symbolize the company's authentic desire to contribute to society (Becker-Olsen et al., 2006), and thus consumers are likely to accept and attribute them to benevolence-motivated giving. Consequently, it is expected that value-driven motives will strengthen CSR authenticity.

CSR practices are viewed as stakeholder-driven if companies are engaged in CSR actions to satisfy the expectations of their stakeholders (Vlachos et al., 2009). While companies embrace this stance from necessity as a response to pressures from stakeholders and society, their CSR activities are positively evaluated if acknowledged by stakeholders as a genuine behavior (Skarmeas and Leonidou, 2013). Consequently, if consumers view CSR motives as stakeholder-driven, CSR activities can be regarded as a sincere activity to revive the expectations and demands of the stakeholders, resulting in a positive effect on CSR authenticity.

Strategic-driven motives refers to beliefs that companies support a cause to achieve business objectives (Ellen et al., 2006). In other words, when a company carry out CSR activities for its strategic purposes, such as customer creation, maintenance, and profits, consumers view them as strategic-driven (Ellen et al., 2006). Although some may perceive them as legitimate because a company needs to be economically viable (Ellen et al., 2006), it is reasonable to view such profit-motivated giving behaviors as a behavior that derives from economic, rather than moral, reasoning (Vlachos et al., 2009). In this regard, if consumers perceive a firm's CSR motives as strategic, CSR authenticity will be weakened.

Egoistic motives refer to beliefs that the company is exploiting rather than supporting the cause (Ellen et al., 2006). If consumers view CSR engagement as an opportunistic and profiteering action, CSR activities are perceived as egoistic and not reciprocal to the social cause because the company is preoccupied with its own interests (Forehand and Grier, 2003). That is, an egoistically intended CSR actions tend to be recognized as a selfish activity for the benefit of business and, thus, they are not likely to be perceived as genuine or sincere. Thus, it is natural to argue that if consumers view a firm's CSR motives as egoistic, it will negatively influence CSR authenticity. 


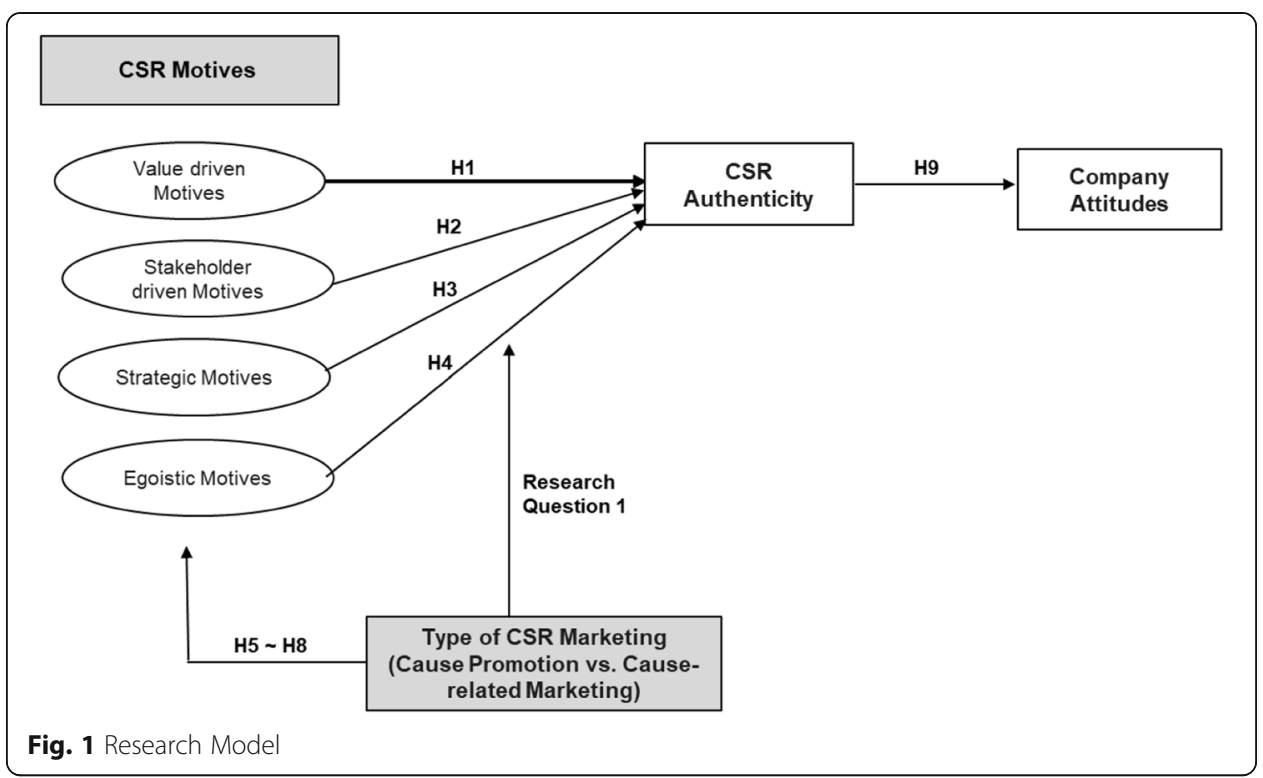

These discussions lead to the following hypotheses to examine the relationship between perceived CSR motives and authenticity.

$<$ Hypothesis $1>$ Value-driven motives will positively influence CSR authenticity.

$<$ Hypothesis $2>$ Stakeholder-driven motives will positively influence CSR authenticity.

$<$ Hypothesis $3>$ Strategic motives will negatively influence CSR authenticity.

$<$ Hypothesis 4 > Egoistic motives will negatively influence CSR authenticity.

Consumers view CSR actions that are aimed at establishing and supporting social values as more value-driven than those aiming at seeking economic profits. As noted earlier, $\mathrm{CP}$ intends to encourage consumers' interests in social issues or public interest and, thus, will be more positively related to value-driven motives than CRM which mainly focuses on addressing social issues through the promotion of product sales.

Companies tend to care more about social issues and public interests that correspond the expectations and requirements of their stakeholders so that more pubic attentions can be drawn (Darley and Lim, 1991). When the primary objectives are compared between CP and CRM, the stakeholder-driven motives appear to be more important for $\mathrm{CP}$. Thus, consumers consider $\mathrm{CP}$ as more stakeholder-driven than CRM, because CRM is basically oriented toward promoting the purchase of a particular product within a limited scope reflecting social values.

In planning and implementing a successful CRM campaign, a variety of strategic factors should be considered, such as a fit between a cause and a company, involvement and intimacy of consumers' interest, and consumer attitudes toward the company (Varadarajan and Menon, 1988). It is understandable that CRM requires more strategic decisions than does $\mathrm{CP}$ and this requirement lies in line with a 
strategic CSR. Thus, it is expected that CRM will have a greater effect on consumers' recognition of firm's strategic motives than CP.

Compared to CRM, CP is characterized as more altruistic, tending to allocate significant part of a company's resources to the public good. In contrast, CRM is rather focused on a company's marketing outcome while supporting social issues through the promotion of product sales. Thus, it is expected that CRM will have a stronger effect on consumer perceptions of an egoistic aspect of CSR motives than CP.

Based on above discussions on the differences in consumer perceptions of CSR motives between CP and CRM, the following hypotheses are proposed.

$<$ Hypothesis $5>$ Perceived value-driven CSR motives will be larger for CP than they are for CRM.

$<$ Hypothesis $6>$ Perceived stakeholder-driven CSR motives will be larger for CP than they are for CRM.

$<$ Hypothesis $7>$ Perceived strategic CSR motives will be larger for CRM than they are for $C P$.

$<$ Hypothesis $8>$ Perceived egoistic CSR motives will be larger for CRM than they are for $C P$.

Previous studies have shown that CSR authenticity positively affects brand attitudes and employees' attitudes toward the company (Brown and Dacin, 1996; Beckman et al., 2009). In addition, persuasion knowledge theory suggests that consumer perceptions of authentic CSR actions result in positive attitudes toward the company's marketing practices. In this vein, this study replicates previous findings by assuming that consumers will show positive reactions to authentic CSR. Thus, the following hypothesis is proposed.

$<$ Hypothesis 9> Perceived CSR authenticity will positively influence consumer attitudes toward the company.

In addition, this study finds it meaningful to examine the relative importance of the four CSR motives in explaining authenticity and to compare their effects between CP and CRM. It is presumed that if consumer perceptions of motives differ between CP and CRM, then their effects on authenticity also differ between CP and CRM. Thus, the following research question is proposed to answer.

$<$ Research Questions $1>$ What is the difference in the effects of perceived CSR motives on CSR authenticity between CP and CRM?

\section{Methodology}

\section{Data collection and sample}

To test study hypotheses and a research question, a face-to-face survey was conducted for a two-week period in the spring of 2018. A convenient sample of 289 respondents participated in the study and they were put into two groups, being exposed to one of 
the two test ad messages; one for CP and the other one for CRM. In order to avoid possible confounding effects of brand name, the test ads were created by using a virtual company name, 'Alpha Water.' A group of 143 respondents was asked to answer questionnaire items after being exposed to $\mathrm{CP}$ messages while the group of 146 respondents was exposed to CRM ad messages. The format, the amount of text messages, and the size of visuals were all balanced between the two test ads. Respondents were asked to answer questionnaire items as soon as they were exposed to the test ads. Their demographic information is presented in Table 1.

\section{Survey instrument and measurement}

The questionnaire included three parts: (1) items measuring four dimensions of CSR motives, (2) three items measuring CSR authenticity and three items measuring company attitudes, and (3) demographic items. The items measuring CSR motives were borrowed from Skarmeas and Leonidou's (2013) study and respondents were then asked to answer authenticity items that that were derived from Alhouti et al.'s (2016) study. All these items were measured by a five-point Likertype scale with anchors ranging from (1) "Strongly disagree" to (5) "Strongly agree." Finally, demographic questions asked gender, age, household income, education level, and marital status.

To ensure that data come from the respondents that are equivalent in terms of research purpose, the sample equivalency was checked based on demographic characteristics. The results of $x^{2}$ and $t$-test showed that the two groups were comparable in gender representation $\left(\chi^{2}=1.421, d f=1, p>.05\right)$, age $(t=2.212, d f=287$, $\mathrm{p}>.05)$, household income $\left(\mathrm{x}^{2}=2.252, \mathrm{df}=3, \mathrm{p}>.05\right)$ and education level $\left(\mathrm{x}^{2}=\right.$ 2.132, $\mathrm{df}=4, \mathrm{p}>.05)$.

\section{Results}

\section{Measurement of reliability and validity}

In order to assess reliability and validity of the constructs, a confirmatory factor analysis was conducted. The model includes six factors- value-driven motives, stakeholder-driven motives, strategic motives, egoistic motives, CSR authenticity, and company attitudes. As shown in Table 2, all the loadings were positive and statistically significant as the values of CR(Composite Reliability) and AVE(Average Variance)for each construct were above the recommended level of .50(AVE) and $.70(\mathrm{CR})$.

To assess the discriminant validity of the measures, the square root of the AVE of each construct with the correlations of that construct was compared with other constructs in the model. Discriminant validity was also achieved as individually constraining each construct correlation to unity significantly $(p<0.01)$ and the square root of the average variance extracted per construct was greater than the off-diagonal correlations (Table 3).

To assess reliability of measurement items for each construct, Cronbach's $\alpha$ was used. As shown in Table 4, most of values were above the acceptable level of .70. (i.e., valuedriven motives 0.66 , stakeholder-driven motives 0.73 , strategic motives 0.70 , egoistic motives 0.69 , CSR authenticity 0.85 , company attitudes 0.84 ). 
Table 1 Demographic Characteristics of Respondents

\begin{tabular}{|c|c|c|c|c|}
\hline \multirow[t]{2}{*}{ Category } & \multirow[t]{2}{*}{ Items } & \multicolumn{2}{|l|}{ Percentage } & \multirow{2}{*}{$\begin{array}{l}\text { Total (289 } \\
\text { People) }\end{array}$} \\
\hline & & $\begin{array}{l}\text { Cause promotion } \\
\text { (143 People) }\end{array}$ & $\begin{array}{l}\text { Cause-related marketing } \\
\text { (146 People) }\end{array}$ & \\
\hline \multirow[t]{2}{*}{ Gender } & Male & $92(64.3 \%)$ & $58(39.7 \%)$ & $150(51.9 \%)$ \\
\hline & Female & $51(35.7 \%)$ & $88(60.3 \%)$ & 139(48.1\%) \\
\hline \multirow[t]{4}{*}{ Age } & $20 \mathrm{~s}$ & $20(14.0 \%)$ & $39(26.7 \%)$ & $59(20.4 \%)$ \\
\hline & $30 \mathrm{~s}$ & $43(30.1 \%)$ & $53(36.3 \%)$ & $96(33.2 \%)$ \\
\hline & $40 \mathrm{~s}$ & $54(37.8 \%)$ & $45(30.8 \%)$ & $99(34.3 \%)$ \\
\hline & 50s and above & $26(18.2 \%)$ & $9(6.2 \%)$ & $35(12.1 \%)$ \\
\hline \multirow[t]{4}{*}{ Education } & High school graduated & $13(9.1 \%)$ & $5(3.4 \%)$ & $18(6.2 \%)$ \\
\hline & University students & $11(7.7 \%)$ & $25(17.1 \%)$ & $36(12.5 \%)$ \\
\hline & University graduated & $100(69.9 \%)$ & $82(56.2 \%)$ & $182(63.0 \%)$ \\
\hline & Graduate school & 19(13.3\%) & $34(23.3 \%)$ & $53(18.3 \%)$ \\
\hline
\end{tabular}

\section{Hypotheses tests}

Hypotheses 1-4 predicted a positive effect of value-driven and stakeholder-driven motives on CSR authenticity and a negative effect of strategic and egoistic motives on CSR authenticity. As shown in Table 5, the results of multiple regression analysis with four CSR motives as independent variables and CSR authenticity as a dependent variable show that value-driven motives $(\mathrm{b}=.538, \mathrm{t}=11.041, p<.001)$ and stakeholder-driven motives $(\mathrm{b}=.183, \mathrm{t}=3.857, p<.000)$ had significantly positive effects on CSR authenticity, supporting Hypothesis 1 and Hypothesis 2. However, it was found that the negative effect of strategic motives was not statistically significant $(b=.055, t=1.096$, $p<.274$ ), rejecting Hypothesis 3. Finally, the results show that the negative effect of egoistic motives was statistically significant $(b=-.210, t=-4.091, p<.000)$, supporting Hypothesis 4.

Table 2 Results of Confirmatory Factor Analysis

\begin{tabular}{|c|c|c|c|c|c|c|}
\hline Factors & Items & $\begin{array}{l}\text { Item } \\
\text { loading }\end{array}$ & $\begin{array}{l}\text { Standard } \\
\text { Error }\end{array}$ & t-value & AVE & C.R \\
\hline \multirow[t]{2}{*}{ Value-driven Motives } & Purely for the public good & .800 & .156 & 9.898 & .519 & .713 \\
\hline & Morally obliged & .631 & - & - & & \\
\hline \multirow{2}{*}{$\begin{array}{c}\text { Stakeholder-driven } \\
\text { Motives }\end{array}$} & Meeting customers' expectation & .700 & .105 & 7.972 & .586 & .738 \\
\hline & Meeting communities' expectation & .826 & - & - & & \\
\hline \multirow[t]{2}{*}{ Strategic Motives } & $\begin{array}{l}\text { Strategic activities for long-term } \\
\text { growth }\end{array}$ & .719 & .101 & 9.672 & .551 & .710 \\
\hline & Getting more customers & .765 & - & - & & \\
\hline \multirow[t]{2}{*}{ Egoistic Motives } & Help themselves & .859 & .140 & 8.785 & .561 & .713 \\
\hline & Tax write-off & .619 & - & - & & \\
\hline \multirow[t]{3}{*}{ CSR Authenticity } & Well-being of society & .826 & .059 & 16.337 & .667 & .859 \\
\hline & Genuine CSR actions & .847 & - & - & & \\
\hline & Truly care for members of society & .784 & .062 & 15.218 & & \\
\hline \multirow[t]{3}{*}{ Company Attitudes } & Positive & .862 & .054 & 17.010 & .665 & .855 \\
\hline & Favorable & .885 & - & - & & \\
\hline & Trustworthy & .685 & .063 & 12.849 & & \\
\hline
\end{tabular}

Note: Model Fitx ${ }^{2}=141.623(\mathrm{df}=62, p<.05) ; \mathrm{RMSEA}=.067, \mathrm{RMR}=.035, \mathrm{GFI}=.936, \mathrm{CFI}=.956, \mathrm{NFI}=.925$ 
Table 3 Discriminant Validity of the Measures

\begin{tabular}{lllllll}
\hline Variable & $\begin{array}{l}\text { Value-driven } \\
\text { Motives }\end{array}$ & $\begin{array}{l}\text { Stakeholder-driven } \\
\text { Motives }\end{array}$ & $\begin{array}{l}\text { Strategic } \\
\text { Motives }\end{array}$ & $\begin{array}{l}\text { Egoistic } \\
\text { Motives }\end{array}$ & $\begin{array}{l}\text { CSR } \\
\text { Authenticity }\end{array}$ & $\begin{array}{l}\text { Company } \\
\text { Attitudes }\end{array}$ \\
\hline $\begin{array}{l}\text { Value-driven } \\
\text { Motives }\end{array}$ & .519 & & & & \\
Stakeholder-driven & $.396^{* *}$ & .586 & & & \\
Motives & $(.157)$ & & & & \\
Strategic Motives & -.137 & $.169^{* *}$ & .551 & & \\
& $(.019)$ & $(.029)$ & & & \\
Egoistic Motives & $-.295^{* *}$ & .018 & $.526^{* *}$ & .561 & \\
& $(.087)$ & $(.001)$ & $(.279)$ & & \\
CSR Authenticity & $.664^{* *}$ & $.401^{* *}$ & -.098 & $-.336^{* *}$ & .667 \\
& $(.196)$ & $(.161)$ & $(.005)$ & $(.099)$ & \\
Company & $.465^{* *}$ & $.292^{* *}$ & .097 & $-.194^{* *}$ & $.627^{* *}$ & .665 \\
Attitudes & $(.214)$ & $(.084)$ & $(009)$. & $(.038)$ & $(.393)$ & \\
\hline
\end{tabular}

Note: Figures on the diagonal are the values of AVE extracted, and values under a diagonal line are correlation, ${ }^{* *} p<0.01$

Hypothesis 5-8 predicted differences in the perceptions of CSR motives between CP and CRM. A series of $\mathrm{t}$-tests were conducted to examine the group difference for each of the four dimensions of CSR motives. As shown in Table 6, respondents' perception of value-driven motives of $\mathrm{CP}$ was larger than that of $\mathrm{CRM}(\mathrm{t}=3.094, \mathrm{df}=287, p<.05)$, supporting Hypothesis 5. Also, perceived stakeholder-driven motives of $\mathrm{CP}$ were found to be larger than that of CRM $(\mathrm{t}=4.431, \mathrm{df}=287, p<.001)$, supporting Hypothesis 6 . However, CP and CRM did not show a significant difference in the perceptions of strategic $(\mathrm{t}=1.298, \mathrm{df}=287, p>.05)$ and egoistic motives $(\mathrm{t}=-.147, \mathrm{df}=287, p>.05)$, rejecting both Hypothesis 7 and 8 .

Hypothesis 9 is concerned with the effect of CSR authenticity and company attitudes. As presented in Table 7, the results from a simple regression analysis show that perceived CSR authenticity significantly influences company attitudes $(\mathrm{b}=0.627, \mathrm{t}=13.644$, $p<.001)$, supporting Hypothesis 9.

A stepwise multiple regression analysis was conducted to answer Research Questions 1. As presented in Table 8, it was found that value-driven motives had the strongest effect on CSR authenticity, followed by stakeholder-driven motives. It was also shown that egoistic motives were least influential and strategic motives had no significant effect on CSR authenticity.

Again, the same regression analysis was conducted for CRM. As shown in Table 9, the strongest effect was found with value-driven motives, followed by egoistic motives. However, the effect of both strategic and egoistic motives on CSR authenticity were least significant for CRM.

Table 4 Reliability of Measures

\begin{tabular}{lll}
\hline Variable & \# of Items & Cronbach's a \\
\hline Value-driven motives & 2 & .668 \\
Stakeholder-driven motives & 2 & .733 \\
Strategic motives & 2 & .709 \\
Egoistic motives & 2 & .691 \\
CSR authenticity & 3 & .859 \\
Company attitudes & 3 & .842 \\
\hline
\end{tabular}


Table 5 Multiple Regression Analysis (CSR Motives and Authenticity)

\begin{tabular}{|c|c|c|c|c|c|c|c|}
\hline \multirow[t]{2}{*}{ Hypothesis } & \multirow[t]{2}{*}{ CSR Motives } & \multicolumn{2}{|c|}{ Unstd. Coefficient } & \multirow{2}{*}{$\begin{array}{l}\text { Std. Coefficient } \\
\text { beta }\end{array}$} & \multirow{2}{*}{$\begin{array}{l}T \\
\text { value }\end{array}$} & \multirow{2}{*}{$\begin{array}{l}P \\
\text { value }\end{array}$} & \multirow[t]{2}{*}{ Results } \\
\hline & & $B$ & S.E. & & & & \\
\hline $\mathrm{H} 1$ & Value-driven & .509 & .046 & .538 & 11.041 & .000 & Supported \\
\hline $\mathrm{H} 2$ & Stakeholder-driven & .163 & .042 & .183 & 3.857 & .000 & Supported \\
\hline $\mathrm{H} 3$ & Strategic & .060 & .055 & .055 & 1.096 & .274 & Rejected \\
\hline $\mathrm{H} 4$ & Egoistic & -.218 & .053 & -.210 & -4.091 & .000 & Supported \\
\hline
\end{tabular}

\section{Discussion and conclusions}

This study intends to examine the role of authenticity in the context of CSR by looking at the relationship between CSR motives and authenticity, comparing consumer perceptions of motives between CP and CRM, and examining the difference in the effects of CSR motives on CSR authenticity for CP and CRM.

\section{Theoretical implications}

First, the findings indicate that respondents' perceptions of value--driven and stakeholder-driven motives have a positive effect on CSR authenticity, while egoistic motives negatively influence authenticity. These results are consistent with the findings of previous studies (Skarmeas and Leonidou, 2013), reconfirming a motive-authenticity linkage in the context of CSR actions. However, the effect of strategic motives was not found significant possibly because of the ambiguity involved in its conceptual meaning. Respondents may have interpreted the meaning of strategic in different ways based on their own values or experiences. One might think that a company decides to contribute to the social cause because it is a right thing to do. Others may perceive it as a part of company's business. In other words, a company is engaged with CSR actions because a company should be economically viable (Ellen et al.,2006).

This study also found that respondents' perceptions of value-driven and stakeholderdriven motives are larger for $\mathrm{CP}$ than they are for CRM, which, in turn, affect company attitudes. And, when the relative strengths of the effects of four categories of motives on CSR authenticity were compared, value-driven motives had the strongest effect for both CP and CRM. On the contrary, stakeholder-driven motives had the second strongest effect for $\mathrm{CP}$, while egoistic motives were least influential. These findings may imply that $\mathrm{CP}$ appealing for consumer responses and participation in supporting social issues makes CSR activities more authentic, if they are seeking social value and public interest for various stakeholders throughout society.

Table 6 T-tests for Differences in Perceived CSR Motives between CP and CRM

\begin{tabular}{llllll}
\hline Hypothesis & CSR Motives & \multicolumn{2}{l}{ Type CSR Marketing } & \multirow{2}{*}{ t-value } & Results \\
\cline { 3 - 4 } & & CP & CRM & & \\
\hline H5 & Value-driven & $3.601(.754)$ & $3.329(.744)$ & $3.094^{*}$ & Supported \\
$\mathrm{H} 6$ & Stakeholder-driven & $3.559(.751)$ & $3.151(.811)$ & $4.431^{* * *}$ & Supported \\
$\mathrm{H} 7$ & Strategic & $3.951(.656)$ & $3.849(.676)$ & 1.298 & Rejected \\
$\mathrm{H} 8$ & Egoistic & $3.580(.706)$ & $3.593(.697)$ & -.147 & Rejected \\
\hline Note: ${ }^{*} p<.05,{ }^{* * *} p<.001$ & & & &
\end{tabular}

Note: ${ }^{*} p<.05,{ }^{* * *} p<.001$ 
Table 7 Simple Regression Analysis (CSR Authenticity and Company Attitudes)

\begin{tabular}{|c|c|c|c|c|c|c|}
\hline \multirow[t]{2}{*}{ Hypothesis } & \multicolumn{2}{|c|}{ Unstd. Coefficient } & \multirow{2}{*}{$\begin{array}{l}\text { Std. Coefficient } \\
\text { Beta }\end{array}$} & \multirow[t]{2}{*}{ t-value } & \multirow[t]{2}{*}{$p$-value } & \multirow[t]{2}{*}{ Results } \\
\hline & $B$ & Std. Error & & & & \\
\hline $\mathrm{H} 9$ & .534 & .039 & .627 & 13.644 & .000 & Supported \\
\hline
\end{tabular}

As expected, the study found that egoistic motives in CP negatively affect CSR authenticity while strategic motives do not have a significant effect on authenticity. This result is in line with the reasons why the aforementioned strategic motives do not significantly affect CSR authenticity.

For CRM, egoistic motives were found to be the second most influential factor, followed by strategic and stakeholder-driven motives, indicating that consumers are still skeptical of using public cause as a marketing tool in CRM. This result implies that consumers have a negative perception that the CSR activity itself is not genuine because CRM itself tend to be perceived as an activity solely for the company's profits.

These findings suggest several theoretical implications. First, positive effects of valuedriven and stakeholder-driven motives on CSR authenticity are confirmed due to their altruistic aspects, while egoistic motives with a clear selfish purpose have a negative effect. These findings are meaningful in the sense that stakeholder-driven motives also contribute to positive perceptions of authenticity. That is, it is not only value-driven CSR actions but also stakeholder-driven CSR activities that may positively affect authenticity, implying that the sincere consideration of stakeholders' interests are still important to the perceptions of CSR authenticity.

Second, significant differences in the degree to which respondents perceive valuedriven and stakeholder-driven motives between CP and CRM imply that CP encouraging consumers' interest in social issues have a greater impact on consumers' view of a company's CSR actions as value-driven or stakeholder driven than CRM supporting social issues to promote product purchases. On the other hand, no significant

Table 8 Stepwise Regression Analysis for CP

\begin{tabular}{lllllll}
\hline Model & $\mathrm{b}$ & Beta & Std. Error & t-value & $\mathrm{F}$ & $\mathrm{R}^{2}$ \\
\hline Constant & 1.047 & - & .235 & $4.464^{* * *}$ & 96.596 & .407 \\
Value-driven Motives & .626 & .638 & .064 & $9.828^{* * *}$ & & \\
Constant & .501 & - & .278 & 1.801 & 57.534 & .451 \\
Value-driven Motives & .566 & .577 & .064 & $8.846^{* * *}$ & & \\
Stakeholder-driven Motives & .214 & .220 & .063 & $3.372^{* *}$ & & \\
Constant & 1.087 & - & .399 & $2.721^{* *}$ & 40.568 & .467 \\
Value-driven Motives & .538 & .547 & .065 & $8.287^{* * *}$ & & \\
Stakeholder-driven Motives & .241 & .248 & .064 & $3.758^{* * *}$ & & \\
Strategic Motives & -.147 & -.130 & .073 & $-2.023^{*}$ & & \\
Constant & 1.477 & - & .438 & $3.370^{* *}$ & 32.183 & .483 \\
Value-driven Motives & .503 & .512 & .066 & $7.575^{* * *}$ & & \\
Stakeholder-driven Motives & .236 & .242 & .064 & $3.707^{* * *}$ & & \\
Strategic Motives & -.063 & -.056 & .083 & -.760 & & \\
Egoistic Motives & -.161 & -.153 & .078 & $-2.053^{*}$ & & \\
\hline
\end{tabular}

Note: ${ }^{*} p<.05,{ }^{* *} p<.01,{ }^{* * *} p<.001$ 
Table 9 Stepwise Regression Analysis for CRM

\begin{tabular}{lllllll}
\hline Model & $\mathrm{b}$ & Beta & Std. Error & t-value & $\mathrm{F}$ & $\mathrm{R}^{2}$ \\
\hline Constant & 1.036 & - & .193 & $5.376^{* * *}$ & 129.328 & .473 \\
Value-driven Motives & .643 & .688 & .057 & $11.372^{* * *}$ & & \\
Constant & .880 & - & .211 & $4.80^{* * *}$ & 67.223 & .485 \\
Value-driven Motives & .592 & .633 & .063 & $9.396^{* * *}$ & & \\
Stakeholder-driven Motives & .103 & .120 & .058 & 1.780 & & \\
Constant & .687 & - & .330 & $2.080^{*}$ & 11.363 & .487 \\
Value-driven Motives & .604 & .646 & .065 & $9.283^{* * *}$ & & \\
Stakeholder-driven Motives & .092 & .107 & .060 & 1.528 & & \\
Strategic Motives & .049 & .048 & .065 & .761 & & \\
Constant & 1.268 & - & .352 & $3.601^{* * *}$ & & 9.333 \\
Value-driven Motives & .542 & 580 & .064 & $8.413^{* * *}$ & & \\
Stakeholder-driven Motives & .116 & .135 & .058 & $2.005^{*}$ & & \\
Strategic Motives & .181 & .176 & .071 & $2.547^{*}$ & & \\
Egoistic Motives & -.267 & -.264 & .071 & $-3.739^{* * *}$ & & \\
\hline
\end{tabular}

Note: ${ }^{*} p<.05,{ }^{* * *} p<.001$

difference in the perceptions of strategic and egoistic motives between CP and CRM implies that still CSR actions are perceived self-centered no matter how they are implemented and viewed by consumers. These findings indicate that different types of CSR activities may be perceived differently depending on their goals, strategies, and tactics especially when they are engaged interactively with consumers in the marketplace.

In addition, the difference in the relative strengths of the effects of four categories of motives on authenticity between CP and CRM suggests a special attention in understanding consumer reactions to CSR activities. While consumers may think that CSR activities are the purest and most authentic when they are appealing to the core value of business and society, the effects may turn out to be different how they are implemented. If CSR activities are mainly intended to support social causes and increase awareness of them, stakeholder-driven motives are still important. On the other hand, if the purpose of CSR actions is perceived to be businessoriented and profit-making, then consumers may consider them as strongly egoistic.

\section{Managerial implications}

These findings suggest managerial implications. First, it is important for CSR practitioners to implement CSR activities that reflect the management philosophy of the firm, the core values of the management, and the mission and vision of the firm so that consumers can recognize the CSR actions as value-driven. On the other hand, as egoistic motives have a negative impact on CSR authenticity, practitioners need to ensure authenticity by emphasizing that CSR activities are not for corporate sales or profit. CSR practitioners also need to develop an effective communication message in their CRM campaign to address value-driven and stakeholder-driven nature of CSR actions. Despite the difference in consumer perceptions between CP and CRM, practitioners may need to develop a communication strategy that strengthens value-oriented 
messages for both cases. However, in planning strategies for CP, specific tactics are required to emphasize stakeholder-driven motives, while CRM campaigns should involve strategies and tactics that help reduce the perceptions of egoistic nature of the campaigns.

\section{Limitations and future study directions}

This study is subject to a few limitations that will lead to future studies. As with many other studies (Skarmeas and Leonidou, 2013), respondents may have a difficulty in identifying clear differences in CSR motives. For example, in the case of strategic motives, there seemed to an ambiguity in understating its clear meaning among respondents. Some might interpret it as corporate management activities for competitive advantage while others view it as self-centered activities for the business itself. Future studies may need to address this issue for a clearer conceptual justification as it is an important part of motives. In addition, although this study compared the effects of CSR motives between CP and CRM, other types of CSR activities need to be studied from a broader perspective, such as 'social marketing' campaign and CSV practices, as they have different goals and strategies, possibly leading to different perceptions of motives and authenticity.

Abbreviations

CP: Cause Promotion; CRM: Cause-related Marketing; CSR: Corporate Social Responsibility

Acknowledgements

We appreciate Professor JongDae Kim, an editor-in-chief of AJSSR, for his valuable comments and suggestions.

Authors' contributions

MJ carried out the research design and the literature review, preformed the statistical analysis and drafted the manuscript. DA conceived the study, and participated in its design and coordination and helped to draft the manuscript. Both authors read and approved the final manuscript.

Funding

Not applicable.

Availability of data and materials

Not applicable.

Competing interests

The authors declare that they have no competing interests.

Received: 23 April 2019 Accepted: 23 July 2019

Published online: 01 August 2019

\section{References}

Alhouti S, Johnson CM, Holloway BB (2016) Corporate social responsibility authenticity: investigating its antecedents and outcome. J Bus Res 69:1242-1249

An DC (2016) Understanding of CSR marketing, Booknet

Becker-Olsen KL, Cusdmore BA, Hill RP (2006) The impact of perceived corporate social responsibility on consumer behaviour. J Bus Res 59(1):46-53

Beckman T, Colwell A, Cunningham PH (2009) The emergence of corporate social responsibility in Chile: the importance of authenticity and social network. J Bus Ethics 86:191-206

Bhattacharya C, Sen S, Korschun D (2006) The role of corporate social responsibility in strengthening multiple stakeholder relationships: a field experiment. J Acad Mark Sci 34(2):158-166

Brown J, Dacin A (1997) The company and the product: corporate associations and consumer product responses. J Mark 61:68-84

Darley WK, Lim JS (1991) Personal relevance as moderator of the effect of public service advertising on behavior. Adv Consum Res 18:303-309

Ellen P, Mohr L, Webb D (2000) Charitable programs and the retailer: do they mix? J Retail 76(3):393-406

Ellen P, Webb D, Mohr L (2006) Building corporate associations: consumer attributions for corporate socially responsible programs. J Acad Mark Sci 34(2):147-157

Forehand MR, Grier S (2003) When is honesty the best policy? The effect of stated company intent on consumer skepticism. J Consum Psychol 13(3):349-356 
Graafland J, Van de Ven B (2006) Strategic and moral motivation for corporate social responsibility. J Corp Citizsh (22): $111-123$

Heider F (1958) The psychology of interpersonal relations. Wiley, New York

Kotler P, Lee N (2013) Good works: marketing and corporate initiative that build a better world and the bottom line. John Wiley \& Sons, Inc. Company

Menon S, Kahn B (2003) Corporate sponsorships of philanthropic activities: when do they impact perception of sponsor brand. J Consum Psychol 13(3):316-327

Mohr LA, Webb DJ (2005) The effects of corporate social responsibility and Price on consumer responses. J Consum Aff 39(1):121-147

Skarmeas D, Leonidou C (2013) When consumers doubt, watch out! The role of CSR skepticism. J Bus Res 66:1831-1838 Varadarajan R, Menon A (1988) Cause related marketing: a Coalignment of marketing strategy and corporate philanthropy. J Mark 52:58-74

Vlachos P, Tsamakos A, Vrechopoulos A, Avramidis P (2009) Corporate social responsibility: attributions, loyalty and the mediating role of trust. Journalof the Academy of Marketing Science 37(2):170-180

\section{Publisher's Note}

Springer Nature remains neutral with regard to jurisdictional claims in published maps and institutional affiliations.

Submit your manuscript to a SpringerOpen ${ }^{\circ}$ journal and benefit from:

- Convenient online submission

- Rigorous peer review

- Open access: articles freely available online

High visibility within the field

- Retaining the copyright to your article

Submit your next manuscript at $\boldsymbol{\nabla}$ springeropen.com 